\title{
Hydrochemical characteristics and the genesis of high arsenic groundwater in the ecotone between polymetallic sulfide mining area and irrigated agricultural area
}

\author{
Y.H. Dong ${ }^{1,2}$, J.L. $\mathrm{Li}^{1} \& \mathrm{~T} . \mathrm{Ma}^{2}$ \\ ${ }^{1}$ School of Environmental Sciences, China University of Geosciences, Wuhan, P.R. China \\ ${ }^{2}$ School of Water Resources and Environmental Engineering, East China University of Technology, Nanchang, \\ P.R. China
}

\begin{abstract}
The goal of this study was to expand existing knowledge to genesis of high arsenic groundwater and to reveal the influence of anthropogenic practices on high arsenic aquifer system, finally to provide the comprehensive theory for developing appropriate water treatment technologies. High arsenic groundwater is distributed at depths of 10-40 $\mathrm{m}$ in the north of Hanjinghouqi county along the Yin Mountains where is the ecotone of the polymetallic sulfide mining area and the irrigation area. Dissolved As concentrations in groundwater are in the range of $0.5 \mu \mathrm{g} \mathrm{L}^{-1}$ to $764.8 \mu \mathrm{g} \mathrm{L}^{-1}$ with an average of $161.6 \mu \mathrm{g} \mathrm{L}^{-1}$. $66.88 \%$ of (103) groundwater samples exceed the standard for allowable arsenic concentration $10 \mu \mathrm{g} \mathrm{L}^{-1}$ in drinking water. High arsenic in the ecotone is geological origin and influenced by anthropogenic activities including irrigation and mining.
\end{abstract}

\section{INTRODUCTION}

An ecotone is a transition zone between two biomes (Fridley et al., 2009) or adjacent patches (Ward et al., 1999). It is where two communities meet and integrate (Pearl et al., 2011). It may be narrow or wide, and it may be local (the zone between a field and forest) or regional (the transition between forest and grassland ecosystems). An ecotone may appear on the ground as a gradual blending of the two communities across a broad area, or it may manifest itself as a sharp boundary line.

The ecotone between polymetallic sulfide mining area and irrigated agricultural area is a mosaic transition zone between two areas affected by human activities. It is used in this study to consider the exchange, mixing and interaction of matter and exchange of energy in surface water, groundwater and sediments between polymetallic sulfide mining area and irrigation area. In this ecotone, migration and interaction of substances among surface water, groundwater, sediments and rocks are susceptible to interference from artificial factors, while formation mechanism of groundwater becomes extremely complicated.

\section{METHODS}

A summary of 103 groundwater samples were collected from the study area Hangjinhouqi County and analyzed for chemical compositions (Fig. 1). The pH, EC and ORP of solution obtained were monitored by portable parallel analyzer (HQ40d, HACH). The

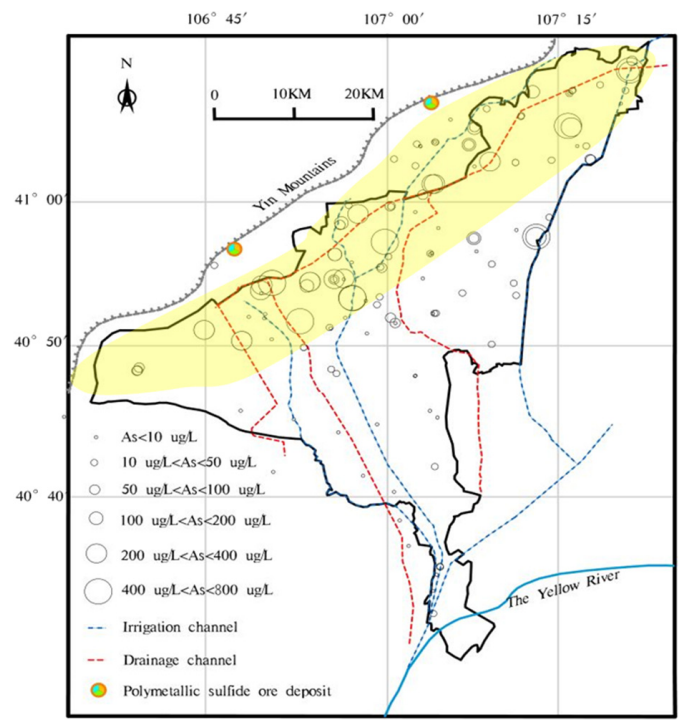

Figure 1. The ecotone between polymetallic sulfide mining area and irrigated agricultural area (in light).

solutions were filtered through membrane filters with $0.45-\mu \mathrm{m}$ pore diameter for chemical analysis. Then aqueous samples were added with 1-2 drops of hydrochloric acid for total As content analysis by Atomic Fluorescence Spectrometry (AFS-820, Titan Instruments). Concentrations of the total $\mathrm{Fe}$, sulfate (calculated as $\mathrm{SO}_{4}^{2-}$ ), and dissolvable sulfide 
(calculated as $\mathrm{S}^{2-}$ ) in filtered solutions were analyzed by portable spectrophotometer (DR2800, HACH).

\section{RESULTS AND DISCUSSION}

\subsection{Groundwater flow field}

Groundwater from the irrigated agricultural area and mining area converges in the ecotone, and flows along the main channel from southwest to east. Water level of a well in the ecotone (the front of the alluvial fans) varied from 0.2 to $8.2 \mathrm{~m}$ below the land surface, and from 0.2 to $3.3 \mathrm{~m}$ below the land surface in the flat plain region. The fluctuation pattern of water level was different between the ecotone and the irrigated agricultural area. That is mainly because the ecotone is far from the Yellow River, where the groundwater is extracted for irrigation, the water level rose when the irrigation ceased and stabilized during winter season without irrigation (Guo et al., 2013).

\subsection{Groundwater hydrochemistry}

In the ecotone, it is obvious that groundwater has a high electrical conductivity, indicating the more dissolved solid than the mining area and irrigation area. Groundwater also has a high average concentration of total dissolved arsenic. The hydrochemical types are complicated in this area (Table 1).

\subsection{Genesis of high arsenic groundwater in the ecotone}

The enrichment processes mainly contain two aspects, groundwater dynamic and groundwater hydrochemical processes. The hydrodynamic processes in the ecotone contains mixing process among the groundwater from the polymetallic sulfide mining area, groundwater from the irrigated agricultural area, and/or water from the main drainage channel in horizontal direction; and the groundwater evaporation the vertical direction. Hydrochemical processes mainly refer to cation exchange, weathering of silicate minerals, reductive dissolution of $\mathrm{Fe} / \mathrm{Mn}$-oxides/hydroxides, and sulfate reduction. Moreover, groundwater nitrate pollution is an essential factor influencing the hydrochemical processes of arsenic enrichment.

\section{CONCLUSIONS}

The groundwater hydrochemistry and distribution of groundwater arsenic in the ecotone were discussed to better understand the groundwater dynamic field and hydrochemical field. The genesis of high arsenic groundwater was revealed.
Table 1. The chemical compositions of groundwater in the ecotone.

\begin{tabular}{|c|c|c|c|c|}
\hline Index & Unit & Max & Min & Average \\
\hline $\mathrm{T}$ & ${ }^{\circ} \mathrm{C}$ & 21.0 & 10.1 & 13.2 \\
\hline $\mathrm{pH}$ & & 9.2 & 6.5 & 7.9 \\
\hline $\mathrm{EC}$ & $\mu \mathrm{S} \mathrm{cm}^{-1}$ & 106300 & 763 & 3595 \\
\hline ORP & $\mathrm{mV}$ & 253.0 & -169.8 & -30.2 \\
\hline DO & $\mathrm{mg} \mathrm{L}^{-1}$ & 7.0 & 1.2 & 3.5 \\
\hline $\mathrm{HCO}_{3}^{-}$ & $\mathrm{mg} \mathrm{L}^{-1}$ & 1276.2 & 141.0 & 615.2 \\
\hline $\mathrm{CO}_{3}^{2-}$ & $\mathrm{mg} \mathrm{L}^{-1}$ & 77.3 & 0.0 & 7.8 \\
\hline Total dissolved As & $\mu \mathrm{g} \mathrm{L}^{-1}$ & 764.8 & 0.5 & 161.6 \\
\hline $\mathrm{As}(\mathrm{III})$ & $\mu \mathrm{g} \mathrm{L}^{-1}$ & 541.1 & 5.3 & 134.5 \\
\hline $\operatorname{As}(\mathrm{V})$ & $\mu \mathrm{g} \mathrm{L}^{-1}$ & 231.0 & 4.4 & 39.8 \\
\hline $\operatorname{As}(\mathrm{p})$ & $\mu \mathrm{g} \mathrm{L}^{-1}$ & 197.3 & 2.6 & 37.2 \\
\hline $\mathrm{Ca}^{2+}$ & $\mathrm{mg} \mathrm{L}^{-1}$ & 457.2 & 2.4 & 90.6 \\
\hline $\mathrm{K}^{+}$ & $\mathrm{mg} \mathrm{L}^{-1}$ & 61.9 & 1.2 & 16.8 \\
\hline $\mathrm{Mg}^{2+}$ & $\mathrm{mg} \mathrm{L}^{-1}$ & 506.9 & 3.8 & 116.4 \\
\hline $\mathrm{Na}^{+}$ & $\mathrm{mg} \mathrm{L}^{-1}$ & 2462.9 & 33.2 & 467.6 \\
\hline $\mathrm{Cl}^{-}$ & $\mathrm{mg} \mathrm{L}^{-1}$ & 4495.3 & 46.3 & 638.1 \\
\hline $\mathrm{SO}_{4}^{2-}$ & $\mathrm{mg} \mathrm{L}^{-1}$ & 1475.7 & BLD & 363.8 \\
\hline $\mathrm{NO}_{3}^{-}$ & $\mathrm{mg} \mathrm{L}^{-1}$ & 190.8 & BLD & 13.7 \\
\hline $\mathrm{F}^{-3}$ & $\mathrm{mg} \mathrm{L}^{-1}$ & 9.45 & BLD & 1.49 \\
\hline $\mathrm{Fe}$ & $\mathrm{mg} \mathrm{L}^{-1}$ & 6.90 & BLD & 0.85 \\
\hline $\mathrm{Mn}$ & $\mathrm{mg} \mathrm{L}^{-1}$ & 0.68 & BLD & 0.14 \\
\hline $\mathrm{TP}$ & $\mathrm{mg} \mathrm{L}^{-1}$ & 0.56 & BLD & 0.05 \\
\hline DOC & $\mathrm{mg} \mathrm{L}^{-1}$ & 77.1 & 0.4 & 13.4 \\
\hline $\mathrm{NH}_{4}^{+}$ & $\mathrm{mg} \mathrm{L}^{-1}$ & 13.4 & BLD & 3.0 \\
\hline $\mathrm{NO}_{2}^{-}$ & $\mathrm{mg} \mathrm{L}^{-1}$ & 0.93 & BLD & 0.04 \\
\hline Dissolved sulfide & $\mu \mathrm{g} \mathrm{L}^{-1}$ & 1206.4 & BLD & 46.1 \\
\hline $\mathrm{PO}_{4}^{3-}$ & $\mathrm{mg} \mathrm{L}^{-1}$ & 4.36 & 0.02 & 0.28 \\
\hline $\mathrm{Fe}^{2+}$ & $\mathrm{mg} \mathrm{L}^{-1}$ & 2.42 & 0.02 & 0.56 \\
\hline
\end{tabular}

Note: BLD: below limit of detection.

\section{ACKNOWLEDGEMENTS}

This work was financially supported by the National Natural Science Foundation of China (No. 41372252) and IAEA Coordinated Research Project (No. $\mathrm{R} 21122 / \mathrm{R} 0$ ).

\section{REFERENCES}

Fridley, J.D., Senft, A.R. \& Peet, R.K. 2009. Vegetation structure of field margins and adjacent forests in agricultural landscapes of the North Carolina piedmont. Castanea 74(4): 327-339.

Guo, H.M., Zhang, Y., Jia, Y.F., Zhao, K., Li, Y. \& Tang X.H. 2013. Dynamic behaviors of water levels and arsenic concentration in shallow groundwater from the Hetao Basin, Inner Mongolia, J. Geochem. Explor. 135: 130-140.

Pearl, S.E., Berg, L.R. \& Martin, D.W. 2011. Biology. Belmont, California.

Ward, J.V., Tockner, K. \& Schiemer, F. 2010. Biodiversity of floodplain river ecosystems: Ecotones and connectivity. River Res. Appl. 15: 125-139. 